\title{
Sakubitril/valsartan'ın koroner arter hastalığı ile ilişkili olaylara etkisi var mı?
}

\author{
Dr. Selda Murat
}

Eskişehir Osmangazi Üniversitesi Tıp Fakültesi, Kardiyoloji Anabilim Dalı, Eskişehir

Kalp yetersizliği (KY) ve koroner arter hastalığı (KAH) birbiriyle yakından ilişkili klinik durumlardır. KY olgularının 2/3'ünde KAH, eşlik eden durum veya etyolojik neden olarak bulunur. Miyokard infraktüsü (MI) sonrası hastaların bir bölümünde KY gelişir. Anjiyotensin dönüştürücü enzim (ACE) inhibitörlerinin, düşük EF'li KY (DEF-KY) hastalarında ölüm ve KY hospitalizasyonu azalttığ1 gösterilmiştir. ${ }^{[1-3]}$ Akut MI sonrası asemptomatik sol ventrikül sistolik disfonksiyonu veya KY gelişen hastalarda ACE inhibitörleri ile ölüm, KY hospitalizasyon ve MI riskinin azaldığı kanıtlanmıştır. Daha önce yapılan çalışmalarda tek başına kardiyovasküler (KV) hastalık veya yüksek KV risk faktörlerine sahip olgularda da RAAS blokajının KV olayları azalttığı ortaya konmuştur. ${ }^{[4,5]}$ Ayrıca anjiyotensin reseptör blokerlerinden (ARB) kandesartan, valsartan ve losartan ile yapılan çalışmalar ARB' lerin DEF-KY veya MI sonrası yüksek riskli hastalarda ACE inhibitörlerine benzer faydalar sağlayabildiğini göstermiştir. ${ }^{[6-8]} \mathrm{Bu}$ nedenlerle renin-anjiyotensin sistem blokajına neprilisin inhibisyonunun eklenmesi ile KV olayların daha da azaltılabileceği düşünülmüş ve PARADIGM HF çalışması koroner sonlanımlar açısından incelenmiştir. ${ }^{[9]}$

PARADIGM HF çalışmasının koroner olaylar üzerine olan sonuçlarının değerlendirildiği analizde enalapril alan hasta populasyonu ile sakubitril/valsartan alan populasyon karşılaştırılmıştır. ${ }^{[9]}$ Çalışma popülasyonu KAH açısından incelediğinde PARADIGM HF'e dahil edilen 8399 hastadan 3634'ünde (\%43.3) MI öyküsü, 4796'sında (\%57.1) KAH öyküsü vardı. Hastaların \%21.4'üne daha önce perkütan koroner girişim (PCI), \% 15.5'ine ise daha önce koroner arter by-pass greft (CABG) operasyonu uygulanmıştı. Hastaların \%11.5'inde unstabil angına pektoris (USAP), \%21.4'ünde stabil angına, \%31.5'inde angiografik olarak kanıtlanmış KAH mevcut idi. KAH'a yönelik kullandıkları tedaviler incelediğinde hastaların \%93'ü beta-bloker, \%56's1 statin, \%52'si asetilsalisilik asit kullanmakta idi.

PARADIGM HF çalışmasının primer sonlanımı KV ölüm veya KY nedeni ile hastaneye yatış idi. Tüm nedenlere bağlı ölüm sekonder sonlanım noktası olarak ele alınmıştı. Koroner sonuçların değerlendirildiği bu analizde iki yeni sonlanım noktası oluşturuldu. Bunlardan birincisi önceden belirlenmiş geniş KV birleşik sonlanım noktası (KV ölüm, KY nedeni ile hastaneye yatış, MI, inme ve resusite edilen ani ölüm) ve ikinci sonlanım noktası Post hoc koroner birleşik sonlanım noktasıydı (KV ölüm, non-fatal MI, unstabil angına nedenli yatış, unstabil angına dışı herhangi bir angına nedenli yatış ve koroner revaskülarizasyon). $\mathrm{Bu}$ yeni analiz de her bir sonlanım noktası ve komponentleri sakubitril/valsartanın etkinliği açısından değerlendirildi.

PARADIGM HF çalışmasının sonuçları sakubitril/ valsartan alan grupta enalapril alan gruba göre primer son nokta olan KV mortalite veya KY hospitalizasyon (HR: $0.80, \mathrm{p}<0.001$ ), tek başına KV mortalite (HR: $0.80, \mathrm{p}<0.001)$ ve tek başına KY hospitalizasyonunun (HR: 0.79, p<0.001) anlamlı olarak daha düşük olduğunu ve sekonder sonlanım noktası olan tüm nedenlere bağlı mortalitenin (HR: 0.84, p<0.001) daha düşük olduğunu göstermişti. Yeni yapılan koroner analiz sonuçlar1 ${ }^{[9]}$ post-hoc koroner birleşik sonlanım noktası (HR: $0.83, \mathrm{p}<0.001$ ) ile önceden belirlenmiş geniş KV birleşik sonlanım noktalarının da (HR: 0.83 , $\mathrm{p}<0.001)$ sakubitril/valsartan grubunda anlamlı olarak daha düşük olduğunu ortaya koydu.

Sonlanım noktalarının her bir komponentine bakıldı ̆̆ında analiz sonuçları MI (HR: 0.96, p=0.73), inme (HR: 0.99, p=0.92), resüsite edilen ani ölüm (HR: 0.56, $\mathrm{p}=0.068$ ) den oluşan önceden belirlenmiş sonlanım noktalarının istatistiksel olarak anlamsız olsa da sakubutril/valsartan lehine olduğunu gösterdi. Koroner bir- 
Tablo 1. PARADIGM HF post-hoc koroner birleşik sonlanım noktası ve komponentleri

\begin{tabular}{|c|c|c|c|c|}
\hline & $\begin{array}{c}\text { Enalapril grubunda } \\
\text { olay sayısı (\%) }\end{array}$ & $\begin{array}{c}\text { Sakubutril/valsartan } \\
\text { grubunda olay sayısı (\%) }\end{array}$ & $\begin{array}{l}\text { Hazard ratio } \\
\text { (\%95 Cl) }\end{array}$ & $\mathrm{p}$ \\
\hline Koroner bileşik son nokta & $857(\% 20.3)$ & $718(\% 17.1)$ & $\begin{array}{c}0.83 \\
(0.75-0.92)\end{array}$ & $<0.001$ \\
\hline KV mortalite & $693(\% 16.5)$ & $558(\% 13.3)$ & $\begin{array}{c}0.80 \\
(0.71-0.89)\end{array}$ & $<0.001$ \\
\hline MI & $119(\% 2.8)$ & $115(\% 2.7)$ & $\begin{array}{c}0.96 \\
(0.74-1.24)\end{array}$ & 0.73 \\
\hline Unstabil angına nedenli hospitalizasyon & $48(\% 1.1)$ & $42(\% 1.0)$ & $\begin{array}{c}0.87 \\
(0.57-1.31)\end{array}$ & 0.50 \\
\hline Koroner revaskülarizasyon & $81(\% 1.9)$ & $79(\% 1.9)$ & $\begin{array}{c}0.96 \\
(0.71-1.31)\end{array}$ & 0.82 \\
\hline
\end{tabular}

MI: Miyokard infraktüsü.

Tablo 2. MI veya KAH öyküsü durumuna göre sakubitril/valsartanın klinik sonlanımlara etkisi

\begin{tabular}{|c|c|c|c|c|c|c|}
\hline & $\begin{array}{c}\text { MI } \\
\text { öyküsü (-) }\end{array}$ & $\begin{array}{c}\text { MI } \\
\text { öyküsü (+) }\end{array}$ & $\begin{array}{l}\text { Etkileşim } \\
\text { p değeri }\end{array}$ & $\begin{array}{c}\text { KAH } \\
\text { öyküsü (-) }\end{array}$ & $\begin{array}{c}\text { KAH } \\
\text { öyküsü (+) }\end{array}$ & $\begin{array}{l}\text { Etkileşim } \\
\text { p değeri }\end{array}$ \\
\hline Primer bileşik son nokta & $\begin{array}{c}0.80 \\
(0.71-0.90)\end{array}$ & $\begin{array}{c}0.79 \\
(0.70-0.90)\end{array}$ & 0.99 & $\begin{array}{c}0.80 \\
(0.72-0.90)\end{array}$ & $\begin{array}{c}0.78 \\
(0.68-0.90)\end{array}$ & 0.78 \\
\hline $\begin{array}{l}\text { Önceden belirlenmiş geniş } \\
\text { KV birleşik son nokta }\end{array}$ & $\begin{array}{c}0.81 \\
(0.72-0.91)\end{array}$ & $\begin{array}{c}0.85 \\
(0.75-0.96)\end{array}$ & 0.51 & $\begin{array}{c}0.78 \\
(0.68-0.89)\end{array}$ & $\begin{array}{c}0.86 \\
(0.78-0.96)\end{array}$ & 0.25 \\
\hline Post hoc koroner birleşik son nokta & $\begin{array}{c}0.79 \\
(0.68-0.91)\end{array}$ & $\begin{array}{c}0.86 \\
(0.75-0.99)\end{array}$ & 0.36 & $\begin{array}{c}0.79 \\
(0.67-0.94)\end{array}$ & $\begin{array}{c}0.84 \\
(0.75-0.96)\end{array}$ & 0.55 \\
\hline KV ölüm & $\begin{array}{c}0.77 \\
(0.66-0.90)\end{array}$ & $\begin{array}{c}0.83 \\
(0.70-0.97)\end{array}$ & 0.52 & $\begin{array}{c}0.78 \\
(0.66-0.93)\end{array}$ & $\begin{array}{c}0.81 \\
(0.70-0.93)\end{array}$ & 0.75 \\
\hline Tüm nedenlere bağlı ölüm & $\begin{array}{c}0.80 \\
(0.70-0.92)\end{array}$ & $\begin{array}{c}0.90 \\
(0.77-1.04)\end{array}$ & 0.24 & $\begin{array}{c}0.82 \\
(0.70-0.96)\end{array}$ & $\begin{array}{c}0.86 \\
(0.75-0.98)\end{array}$ & 0.64 \\
\hline
\end{tabular}

MI: Miyokard infraktüsü; KAH: Koroner arter hastalığı; KV: Kardiyovasküler.

leşik sonlanım noktaları olan KV nedenli ölüm (HR: 0.80, $\mathrm{p}<0.001$ ), non-fatal MI (HR: 0.96, $\mathrm{p}=0.73$ ), unstabil angına nedenli yatıs (HR: $0.87, \mathrm{p}=0.50)$ ve koroner revaskülarizasyon (HR: 0.96, $\mathrm{p}=0.82$ ) sakubitril/valsartan lehine daha düşük bulundu. Sakubitril/valsartan ile enalaprilin post hoc koroner bileşik sonlanım noktası ve komponentlerine olan etkisi Tablo 1'de özetlenmiştir.

Çalışmaya dahil edilen hastalarda MI ve KAH öyküsü dikkate alınarak da sakubitril/valsartanın etkinliği açısından istatistiksel değerlendirme yapılmıştır. MI öyküsü olan ve olmayan olgular ile KAH öyküsü olan ve olmayan olgular her üç sonlanım noktası ve sonlanım noktalarının komponentleri açısından incelenmiştir (Tablo 2). Söz konusu analiz sonuçları sakubitril/valsartan'ın KAH bulunan ve bulunmayanlar ile MI öyküsü bulunan ve bulunmayanlarda benzer klinik yararlar sağladığını göstermektedir.

PARADIGM HF çalışmasının koroner sonuçlarının incelenmesinde ki amaç sakubitril/valsartanın KY ile ilişkili olayların dişında koroner arter hastalığ1 ile ilişkili olaylar üzerindeki etkisini incelemek ve neprilisin inhibisyonunun miyokard iskemisi ve atero-trombozun neden olduğu olay riskini azaltıp azaltmadığını değerlendirmekti. Sakubitril/valsartan, hemodinamik mekanizmalarla (örn. Sol ventrikül duvar stresinde azalma) miyokardiyal iskemi riskini azaltabilir ve ayrıca C-natriüretik peptidin (CNP) lokal olarak parçalanmasını önleyerek ve hücre içi siklik GMP konsantrasyonundaki artışlarla koroner dolaşım üzerinde olumlu etkilere sahip olabilir. ${ }^{[10-12]}$ 
PARADIGM-HF çalışmasında post hoc koroner birleşik sonlanım noktasının (KV nedenli ölüm, nonfetal MI, USAP nedenli yatış ve koroner revaskülarizasyon) risk oranı ARNI ile anlamlı azalmıştır. Ancak her bir koroner olayın ortaya çıkma riskine bakıld1ğinda asıl etkinin KV mortalitede ki azalmadan kaynaklandığı, MI ve UAP üzerine enalaprilden farklı bir etkisinin olmadığ 1 görülmüştür. Bu sonuçlarla sakubitril/valsartanın koroner olaylara enalaprilden üstün bir etkisinin olup olmadığını söylemek mümkün değildir. Yine de enalaprille kıyaslandığında sakubitril/ valsartanın KV mortalite ve birleşik non-fatal koroner olayları azalttığı görülmüştür. ${ }^{[9]}$ Ayrıca sakubitril/ valsartan'in KAH bulunan ve bulunmayanlar ile MI öyküsü bulunan ve bulunmayanlarda benzer klinik yararlar sağladığı söylenebilir.

\section{Kaynaklar}

1. CONSENSUS Trial Study Group. Effects of enalapril on mortality in severe congestive heart failure. Results of the Cooperative North Scandinavian Enalapril Survival Study (CONSENSUS). N Engl J Med 1987;316:1429-35.

2. SOLVD Investigators, Yusuf S, Pitt B, Davis CE, Hood WB, Cohn $\mathrm{JN}$. Effect of enalapril on survival in patients with reduced left ventricular ejection fractions and congestive heart failure. $\mathrm{N}$ Engl $\mathrm{J}$ Med 1991;325:293-302.

3. SOLVD Investigators, Yusuf S, Pitt B, Davis CE, Hood WB Jr, Cohn JN. Effect of enalapril on mortality and the development of heart failure in asymptomatic patients with reduced left ventricular ejection fractions. N Engl J Med 1992;327:685-91.

4. Heart Outcomes Prevention Evaluation Study Investigators, Yusuf S,
Sleight P, Pogue J, Bosch J, Davies R, et al. Effects of an angiotensin-converting-enzyme inhibitor, ramipril, on cardiovascular events in high-risk patients. N Engl J Med 2000;342:145-53.

5. Fox KM; EURopean trial On reduction of cardiac events with Perindopril in stable coronary Artery disease Investigators. Efficacy of perindopril in reduction of cardiovascular events among patients with stable coronary artery disease: randomised, double-blind, placebo-controlled, multicentre trial (the EUROPA study). Lancet 2003;362:782-8.

6. Granger CB, McMurray JJ, Yusuf S, Held P, Michelson EL, Olofsson $B$, et al. Effects of candesartan in patients with chronic heart failure and reduced left-ventricular systolic function intolerant to angiotensin-converting-enzyme inhibitors: the CHARM-Alternative trial. Lancet 2003;362:772-6.

7. Cohn JN, Tognoni G; Valsartan Heart Failure Trial Investigators. A randomized trial of the angiotensin-receptor blocker valsartan in chronic heart failure. N Engl J Med 2001;345:1667-75.

8. Konstam MA, Neaton JD, Dickstein K, Drexler H, Komajda M, Martinez FA, et al. Effects of high-dose versus low-dose losartan on clinical outcomes in patients with heart failure (HEAAL study): a randomised, double-blind trial. Lancet 2009;374:1840-8.

9. Mogensen UM, Køber L, Kristensen SL, Jhund PS, Gong J, Lefkowitz MP, et al. The effects of sacubitril/valsartan on coronary outcomes in PARADIGM-HF. Am Heart J 2017;188:35-41.

10. Naruko T, Ueda $M$, van der Wal AC, van der Loos CM, Itoh H, Nakao $\mathrm{K}$, et al. C-type natriuretic peptide in human coronary atherosclerotic lesions. Circulation 1996;94:3103-8.

11. Hobbs A, Foster P, Prescott C, Scotland R, Ahluwalia A. Natriuretic peptide receptor-C regulates coronary blood flow and prevents myocardial ischemia/reperfusion injury: novel cardioprotective role for endothelium-derived C-type natriuretic peptide. Circulation 2004;110:1231-5.

12. Wright RS, Wei CM, Kim CH, Kinoshita M, Matsuda Y, Aarhus LL, et al. C-type natriuretic peptide-mediated coronary vasodilation: role of the coronary nitric oxide and particulate guanylate cyclase systems. J Am Coll Cardiol 1996;28:1031-8. 